\title{
FAKTOR YANG BERHUBUNGAN DENGAN KEJADIAN KOMPLIKASI PERSALINAN DI RSUD INDRAMAYU TAHUN 2018
}

\author{
Tating Nuraeni \\ Universitas Wiralodra, Jl. Ir. H. Juanda KM 03 Indramayu Jawa Barat, \\ tatingnuraeni@unwir.ac.id
}

https://doi.org/10.31943/gemawiralodra.Vol9.Iss2.347

\begin{abstract}
ABSTRAK
Komplikasi persalinan merupakan gangguan kesehatan yang sangat berbahaya bagi ibu bersalin karena dapat menyebabkan kematian pada ibu maupun pada janin. Kematian ibu di rumah sakit disebabkan karena banyaknya kasus kegawat-daruratan pada kehamilan, persalinan dan nifas. Penyebab langsung kematian ibu yang terbanyak adalah: perdarahan, hipertensi pada kehamilan, partus macet, infeksi dan komplikasi aborsi. Penelitian ini bertujuan untuk mengetahui faktor yang berhubungan dengan kejadian komplikasi persalinan di RSUD Indramayu tahun 2018. Rancangan penelitian menggunakan metode analitik dengan pendekatan Crossectional Study untuk melihat hubungan antara hipertensi, dan berat badan lebih dengan kejadian komplikasi persalinan. Jumlah sampel yang digunakan sebanyak 94 orang yang merupakan pasien bersalin di RSUD Indramayu. Hasil dari penelitian menunjukkan bahwa terdapat hubungan antara hipertensi, dan berat badan lebih dengan kejadian komplikasi persalinan dengan nilai masing-masing: hipertensi ( $\rho$ value $=0,002)$, dan berat badan lebih $(\rho$ value $=0,000)$. Kesimpulan pada penelitian ini yaitu ada hubungan hipertensi dan berat badan lebih terhadap kejadian komplikasi persalinan. Kegiatan kesehatan ibu berupa KB, asupan gizi seimbang, dan cek kehamilan secar rutin adalah langkah untuk mencegah terjadinya komplikasi persalinan.
\end{abstract}

\section{Kata Kunci : Komplikasi persalinan, hipertensi, berat badan lebih}

\begin{abstract}
Complications of delivery is a health disorder that is very dangerous for mothers because it can cause maternal deaths and the fetus. Maternal deaths in hospitals are caused by many cases of emergencies in pregnancy, childbirth and childbirth. The most immediate causes of maternal death are: bleeding, hypertension in pregnancy, partus stuck, infection and complications of abortion. This study aims to determine the factors associated with the incidence of birth complications in hospitals Indramayu 2018. Research design uses analytical method with Cross sectional Study approach to see the relationship between hypertension, and more weight with the incidence of labor complication. The number of samples used are 94 people who are maternity patients in hospital Indramayu. Results: indicated that there was a correlation between hypertension, and overweight with the incidence of birth complications with their respective values: hypertension ( $\rho$ value $=$ 0.002 ), and overweight ( $\rho$ value $=0.000$ ). Conclusions and suggestions, there is a correlation of hypertension and overweight to the incidence of labor complications. Maternal health activities in the form of family planning, balanced nutrition, and routine pregnancy checks are steps to prevent birth complications.
\end{abstract}

Keywords: Complications labor, age, hypertension, overweight 


\section{PENDAHULUAN}

Kesehatan ibu termasuk salah satu isu krusial dalam pencapaian pembangunan kesehatan di seluruh dunia. Pelayanan kesehatan ibu tidak hanya dapat digunakan untuk menentukan pembangunan kesehatan suatu negara, tetapi dapat digunakan untuk investasi bagi peningkatan kualitas sumber daya manusia di masa mendatang (Syafrudin dan Hamidah, 2009). Ibu adalah anggota keluarga yang berperan penting dalam mengatur semua terkait urusan rumah tangga, pendidikan anak dan kesehatan seluruh keluarga, sehingga upaya peningkatan penyelenggaraaan kesehatan ibu perlu mendapatkan prioritas dan perhatian khusus (Kemenkes RI, 2014).

Target AKI di Indonesia berdasarkan MDGs di tahun 2015 adalah 102 per 100.000 kelahiran hidup (Kemenkes RI, 2014). Berdasarkan Survei Demografi dan Kesehatan Indonesia (SDKI) tahun 2012, AKI (yang berkaitan dengan kehamilan, persalinan dan nifas) sebesar 359 per 100.000 kelahiran hidup. Angka kematian ibu menduduki peringkat pertama jika dibandingkan dengan negara-negara tetangga di Kawasan Assosiation of Southeast Asian Nations (ASEAN). Pada tahun 2007, ketika AKI di Indonesia mencapai 228, AKI di Singapura hanya 6 per 100.000 kelahiran hidup, Brunei 33 per 100.000 kelahiran hidup, Filipina 112 per 100.000 kelahiran hidup, serta Malaysia dan Vietnam sama-sama mencapai 160 per 100.000 kelahiran hidup (Kemenkes RI, 2015).

Penduduk Indonesia pada tahun 2007 adalah 225.642.000 jiwa dengan AKI 228 per 100.000 kelahiran hidup yang berarti ada $9.774 \mathrm{ibu}$ meninggal per tahun atau 1 ibu meninggal tiap jam oleh sebab yang berkaitan dengan kehamilan, persalinan, dan nifas. Penyebab langsung kematian ibu sebesar 90\% terjadi pada saat persalinan dan segera setelah persalinan (Saifuddin, 2009).

Kematian ibu di rumah sakit disebabkan karena banyaknya kasus kegawatdaruratan pada kehamilan, persalinan dan nifas. Penyebab langsung kematian ibu yang terbanyak adalah: perdarahan, hipertensi pada kehamilan, partus macet, infeksi dan komplikasi aborsi. Sejak 10 tahun terakhir, angka kematian ibu dan bayi di Indonesia berada pada tingkat yang tertinggi diantara negara berkembang di dunia dan belum menunjukan adanya kecenderungan menurun walaupun sudah cukup banyak upaya yang dilakukan. Bahkan diantara negara ASEAN angka kematian ibu melahirkan mencapai 307 per 100.000 kelahiran (Asrinah, 2010).

Penambahan berat badan ibu hamil yang dianjurkan antara 7,5-20 kg. Karena berat badan naik yang berlebihan mempunyai risiko terjadinya diabetes gestasional (penambahan kadar gula darah karena adanya proses kehamilan) atau terjadinya 
preeklampsi (keracunan kehamilan dimana terjadi kenaikan tekanan darah). Demikian pula sebaliknya pada wanita yang penambahan berat badannya kurang, asupan dalam tubuh pun berkurang sehingga akan menghambat pertumbuhan janin dalam kandungan. Hal tersebut dapat mengakibatkan BBLR (Berat Bayi Lahir Rendah) dan gangguan kehamilan lainnya (Surininah, 2008).

Hipertensi adalah penyakit kronis yang paling umum pada wanita hamil dengan usia tua. Wanita pada usia 30-40 tahun mempunyai angka kejadian yang lebih tinggi untuk mengalami hipertensi akibat kehamilan dibanding wanita muda. Sekitar $20 \%$ dari semua wanita yang mengalami hiperetensi kronis mengalami pre-eklampsia, dan $25 \%$ dari wanita yang hipertensi akibat kehamilan juga mengalaminya. Hipertensi meningkatkan risiko abrupsio plasenta. Situasi ini dapat menyebabkan perdarahan hebat dan syok, yang membahayakan kondisi ibu dan bayi (Pudiastuti, 2011).

Menurut laporan KIA tahun 2017, AKI berjumlah 229 per 100.000 kelahiran hidup dan meningkat pada tahun 2017 yakni 247 per 100.000 kelahiran hidup. Penyebab utama kematian ibu di Provinsi Jawa Barat adalah perdarahan, hipertensi, dan infeksi. Sedangkan AKI di Kabupaten Indramayu berdasarkan laporan dari rumah sakit dan Puskemas cenderung berfluktuasi selama lima tahun terakhir. Tujuan penelitian ini yaitu mengetahui faktor yang berhubungan dengan kejadian komplikasi persalinan di RSUD Indramayu tahun 2018.

\section{METODE PENELITIAN}

Jenis penelitian ini yang digunakan adalah metode Analitik dengan pendekatan Cross sectional Study. Populasi dalam penelitian adalah semua pasien bersalin di RSUD Indramayu pada saat penelitian sedangkan sampel adalah sebagian dari populasi. Besar sampel dalam penelitian sebanyak 94 responden. Pengambilan sampel menggunakan teknik Accidental Sampling. Pengumpulan data diperoleh dari data primer dengan menggunakan kuesioner dan data sekunder yang didapatkan dari data rekam medik di RSUD Indramayu pada tahun 2018. Analisis data menggunakan uji Chi Square.

\section{HASIL DAN PEMBAHASAN}

\section{Hasil}

Penelitian dilakukan terhadap 94 sampel ibu hamil. Adapun yang diteliti terdiri dari variabel dependen yaitu komplikasi persalinan dan variabel independen terdiri dari hipertensi dan berat badan lebih. Berdasarkan hasil analisis univariat pada Tabel 1 pada 
variabel hipertensi menunjukkan bahwa responden yang mengalami komplikasi persalinan lebih banyak yang hipertensi yaitu sebanyak 34 orang $(77,3 \%)$ dibanding yang tidak hipertensi yaitu 22 orang $(44,0 \%)$. Sedangkan responden yang tidak mengalami komplikasi persalinan lebih banyak yang tidak hipertensi yaitu sebanyak 28 orang $(56,0 \%)$ dibanding yang hipertensi yaitu 10 orang $(22,7 \%)$.

Pada variabel berat badan lebih menunjukkan bahwa responden yang mengalami komplikasi persalinan lebih banyak yang memiliki berat badan lebih yaitu sebanyak 30 orang $(88,2 \%)$ dibanding yang tidak memiliki berat badan lebih yaitu 26 orang $(43,3 \%)$. Sedangkan responden yang tidak mengalami komplikasi persalinan lebih banyak pada responden yang tidak memiliki berat badan lebih yaitu sebanyak 34 orang $(56,7 \%)$ dibanding yang memiliki berat badan lebih yaitu 4 orang $(11,8 \%)$.

Tabel 1. Analisis Bivariat

\begin{tabular}{|c|c|c|c|c|c|c|}
\hline \multirow{3}{*}{ Variabel Independen } & \multicolumn{4}{|c|}{ Komplikasi Persalinan } & \multirow{2}{*}{ Total } & \multirow{3}{*}{$P$ value } \\
\hline & \multicolumn{2}{|c|}{$\mathrm{Ya}$} & \multicolumn{2}{|c|}{ Tidak } & & \\
\hline & $\mathrm{n}$ & $\%$ & $n$ & $\%$ & $\mathrm{~N}$ & \\
\hline \multicolumn{7}{|l|}{ Hipertensi } \\
\hline $\mathrm{Ya}$ & 34 & 77,3 & 10 & 22,7 & 44 & \multirow{3}{*}{0,002} \\
\hline Tidak & 22 & 44,0 & 28 & 56,0 & 50 & \\
\hline Jumlah & 56 & 59,6 & 38 & 40,4 & 94 & \\
\hline \multicolumn{7}{|l|}{ Berat Badan Lebih } \\
\hline Ya & 30 & 88,2 & 4 & 11,8 & 34 & \multirow{3}{*}{0,000} \\
\hline Tidak & 26 & 43,3 & 34 & 56,7 & 60 & \\
\hline Jumlah & 56 & 59,6 & 38 & 40,4 & 94 & \\
\hline
\end{tabular}

Berdasarkan hasil uji Chi Square diperoleh nilai $\rho=0,002$ atau $(\rho<0,05)$. Maka Ho pada penelitian ini ditolak artinya, bahwa ada hubungan antara hipertensi dengan kejadian komplikasi persalinan. Sedangkan variabel berat badan lebih diperoleh nilai $\rho$ $=0,000$ atau $(\rho<0,05)$. Maka Ho pada penelitian ini ditolak artinya, bahwa ada hubungan antara berat badan lebih dengan kejadian komplikasi persalinan.

\section{Pembahasan}

Hipertensi, yang sebagian besar disebabkan oleh faktor keturunan, kebiasaan makan garam, stress dan gangguan metabolisme lemak dan karbohidrat, merupakan gangguan kesehatan yang diderita 10 persen-30 persen orang dewasa di semua negara di dunia. Tekanan darah dalam kehidupan seseorang bervariasi secara alami. Tekanan darah juga dipengaruhi oleh aktivitas fisik, akan lebih tinggi pada saat melakukan aktivitas fisik dan lebih rendah ketika beristirahat (Indriasari, 2009). 
Hasil penelitian faktor hubungan hipertensi dengan kejadian komplikasi persalinan yang dilakukan di RSUD Indramayu tahun 2018, memperlihatkan $\rho$ value $0,002<0,05$ hal ini menunjukkan bahwa terdapat hubungan antara hipertensi dengan kejadian komplikasi persalinan. Risiko hipertensi karena kehamilan dipertinggi pada keadaan di mana pembentukan antibodi penghambat terhadap tempat-tempat yang bersifat antigen pada plasenta terganggu. Peluang bahwa adanya mekanisme imunologis di samping endokrin dan genetik turut terlibat dalam proses terjadinya preekklamsia dan masih menjadi masalah yang mengundang perhatian. Preeklamsia mungkin lebih sering terdapat pada wanita dari keluarga yang tidak mampu; namun bisa juga terjadi pada wanita dengan ekonomi yang menengah ke atas. Bahkan pengamatan menyebutkan bahwa makanan yang kurang mengandung protein sebagai penyebab penurunan insiden eklamsia. Kehamilan juga menyebabkan wanita hamil kekurangnan nutrisi. Seharusnya preeklamsia ditemukan pada multipara dari pada nulipara, tetapi kenyataannya sama-sama dapat terjadi preeklamsia.

Preeklampsia dapat disebut sebagai hipertensi yang diinduksi oleh kehamilan atau penyakit hipertensi akut pada kehamilan. Preeklampsia tidak semata-mata terjadi pada wanita muda pada kehamilan pertamanya. Preeklampsia ini paling sering terjadi selama trimester terakhir kehamilan. Hipertensi biasanya timbul lebih dahulu daripada tanda-tanda lain. Diagnosis hipertensi ditegakkan dari adanya peningkatan tekanan darah dengan sistolik $\geq 140 \mathrm{mmHg}$ dan diastolik $\geq 90 \mathrm{mmHg}$ (Wiknjosastro, 2007).

Riwayat hipertensi adalah ibu yang pernah mengalami hipertensi sebelum hamil atau sebelum umur kehamilan 20 minggu. Ibu yang mempunyai riwayat hipertensi berisiko lebih besar mengalami preeklamsi, serta meningkatkan morbiditas dan mortalitas maternal dan neonatal lebih tinggi. Diagnosa preeklamsi ditegakkan berdasarkan peningkatan tekanan darah yang disertai dengan proteinuria atau edema anasarka (Sitanggang dan Nasution, 2008).

Berat badan lebih ternyata juga menjadi ancaman yang cukup serius bagi ibu hamil. Tidak hanya pada masa kehamilan, ibu yang memiliki kelebihan berat badan, kemungkinan akan mengalami masalah ketika persalinan dan pasca persalinan. Kebanyakan ibu hamil mengalami obesitas karena kelebihan makan. Mitos yang mengatakan bahwa ibu hamil makan untuk dua orang menjadikan para ibu hamil makan dengan porsi berlebih. Akhirnya, terjadilah penumpukan kalori dan sisa asupan energi yang berujung pada diabetes. Mitos tersebut keliru, sebenarnya kebutuhan makan ibu hamil hanya naik rata-rata 10-15\% (Manuaba, 2010). 
Hal ini merupakan masalah gizi karena kelebihan kalori, biasanya disertai kelebihan lemak dan protein hewani, kelebihan gula dan garam yang kelak bisa merupakan faktor risiko terjadinya berbagai jenis penyakit degeneratif, seperti diabetes melitus, hipertensi, penyakit jantung koroner, reumatik dan berbagai jenis keganasan (kanker) dan gangguan kesehatan lain. Hubungan antara berat badan ibu dengan risiko preeklamsia bersifat progresif, meningkat dari 4,3\% untuk wanita dengan indeks massa tubuh kurang dari 19,8 kg/m2 terjadi peningkatan menjadi 13,3\% untuk mereka yang indeksnya $\geq 35 \mathrm{~kg} / \mathrm{m} 2$ (Febry, 2013).

Hasil penelitian faktor hubungan berat badan lebih dengan kejadian komplikasi persalinan yang dilakukan di RSUD Indramayu tahun 2018, memperlihatkan $\rho$ value $0,000<0,05$ hal ini menunjukkan bahwa terdapat hubungan antara berat badan lebih dengan kejadian komplikasi persalinan. Penelitian ini didukung oleh penelitian lain yang menyebutkan bahwa wanita yang kelebihan berat badan pada trimester pertama kehamilan maupun yang berat badannya melonjak naik, punya kemungkinan lebih besar akan hamil lebih lama serta mengalami komplikasi.

Hasil analisa data dari Swedish Medical Birth Register menyebutkan bahwa pada perempuan yang melahirkan antara tahun 1998 dan 2002, dari 143.519 kehamilan, 6,8\% melahirkan dengan "tanggal mundur" yang artinya lebih dari 42 minggu. Kehamilan normal berlangsung selama 40 minggu. Dari data tersebut dapat diketahui bahwa kehamilan yang melewati masa normal, lebih banyak dialami ibu hamil yang pada trimester pertama memiiliki indeks massa tubuh (IMT) lebih tinggi maupun mereka yang berat badannya melonjak tinggi saat hamil. Hal tersebut dapat memicu terjadinya preeclampsia, kaki bengkak dan terjadi penimbunan cairan tubuh. Serta infeksi pasca persalinan, meningkat karena proses persalinan berlangsung sulit dan lama (Proverawati dan Kusumawati, 2011).

Menurut penelitian Rode, angka komplikasi selama kehamilan dan persalinan meningkat dengan meningkatnya IMT sebelum kehamilan pada wanita, khususnya pada wanita nulipara. Wanita mempunyai peningkatan risiko persalinan seksio sesarea dengan meningkatnya IMT dan ada hubungan dengan paritas. Sedangkan Crane dkk mengemukakan bahwa wanita dengan berat badan lebih dan kegemukan mempunyai satu peningkatan risiko persalinan seksio sesarea darurat dimana persalinan sesarea merupakan pilihan wajib yang meningkat pada wanita kegemukan.

Hasil penelitian Murphy dkk (2007) mendapatkan temuan bahwa satu faktor yang meningkatkan kemungkinan persalinan seksio sesarea adalah IMT ibu sebelum 
hamil > 30 dengan risiko sebesar 2,4 kali pada ibu dengan IMT < 30 (Nasution, 2008). Dalam proses kehamilan akan terjadi pertambahan berat badan. Hasil penelitian Shepard, Summer, Braken menyimpulkan bahwa risiko persalinan seksio sesarea meningkat dengan meningkatnya IMT dan penambahan berat badan kehamilan daripada median IMT seseorang. Kenaikan berat badan proporsional adalah suatu prediktor penting dari seksio sesarea untuk wanita yang kurus, IMT yang tinggi juga merupakan prediktor meningkatnya risiko seksio sesarea (Sediaoetama, 2010).

Kondisi fisik yang menurun seperti kelelahan dan malnutrisi dapat meningkatkan intensitas nyeri yang dirasakan. Dengan demikian dapat dikatakan di dalam proses persalinan diperlukan kekuatan atau energi yang cukup besar, karena jika ibu mengalami kelelahan dalam persalinan tidak cukup toleran dalam menghadapi rasa nyeri yang timbul sehingga intensitas nyeri yang dirasakan semakin tinggi (Yanti, 2009).

\section{KESIMPULAN}

Berdasarkan hasil penelitian dan pembahasan disimpulkan bahwa:

1. Terdapat hubungan antara hipertensi dengan kejadian komplikasi persalinan di RSUD Indramayu ( $\mathrm{p}$ value $=0,002)$.

2. Terdapat hubungan antara berat badan lebih dengan kejadian komplikasi persalinan di RSUD Indramayu ( $\mathrm{p}$ value $=0,000$ ).

\section{SARAN}

Bagi ibu hamil yang hipertensi disarankan agar sering mengontrol tekanan darahnya serta meminimalkan mengonsumsi makanan dengan kandungan garam yang tinggi serta sebaiknya penuhi gizi dengan pola makan seimbang serta menyesuaikannya dengan berat badan.

\section{UCAPAN TERIMAKASIH (Opsional)}

Peneliti mengucapkan terimakasih kepada Direktur RSUD Indramayu dan Jajarannya serta para ibu yang telah membantu peneliti demi kelancaran pelaksanaan penelitian ini.

\section{DAFTAR PUSTAKA}

Asrinah. Et al. 2010. Asuhan Kebidanan Masa Persalinan. Yogyakarta: Graha Ilmu..

Febry, A.B. 2013. Ilmu Gizi untuk Praktisi Kesehatan. Yogyakarta: Graha Ilmu.. 
Indriasari. 2009. Perilaku Kesehatan Ibu Pra dan Pasca Persalinan (Studi Deskriptif Tentang Perilaku Kesehatan ibu Pra dan Pasca Persalinan di Daerah Pemukiman Kumuh Kelurahan Gubeng Kecamatan Gubeng Surabaya). Tesis. Fakultas Kesehatan Masyarakar Universitas Airlangga Surabaya.

Kemenkes RI. 2014. Situasi Kesehatan Ibu. Jakarta: Infodatin Kemenkes RI..

Kemenkes RI. 2015. Profil Kesehatan Indonesia 2014. Jakarta.

Manuaba. 2010. Ilmu Kebidanan.Penyakit Kandungan dan Keluarga Berencana Untuk pendidikan Bidan. Jakarta: EGC..

Notoatmodjo S. 2010. Metodologi Penelitian Kesehatan. Jakarta: Rineka Cipta..

Prasetyawati dan Arsita E. 2012. Kesehatan Ibu dan Anak (KIA) Dalam Millenium Development Goals. Yogyakarta: Nuha Medika..

Proverawati dan Kusumawati. 2011. Ilmu Gizi untuk Keperawatan dan Gizi Kesehatan. Nuha Medika. Yogyakarta.

Pudiastuti, Ratna. D. 2011. Buku Ajar Kebidanan. Jakarta: Nuha Medika..

Saifuddin AB. 2009. Ilmu Kebidanan Kematian Ibu dan Perinatal. Jakarta: Bina Pustaka.

Sitanggang, B., Nasution, S.S. 2008. Faktor-faktor Kesehatan pada Ibu Hamil. Skripsi. Fakultas Keperawatan, Universitas Sumatera Utara.

Suririnah. 2008. Buku Pintar Kehamilan \& Persalinan. Jakarta: Gramedia Pustaka Utama.

Syafrudin dan Hamidah. 2009. Kebidanan Komunitas. Jakarta: EGC.

Wiknjosastro, Hanifa. 2007. Ilmu Kebidanan. Jakarta: Yayasan Bina Pustaka Sarwono Prawirohardjo.

Yanti. 2009. Buku Ajar Asuhan Kebidanan Persalinan. Yogyakarta: Pustaka Rihama. 